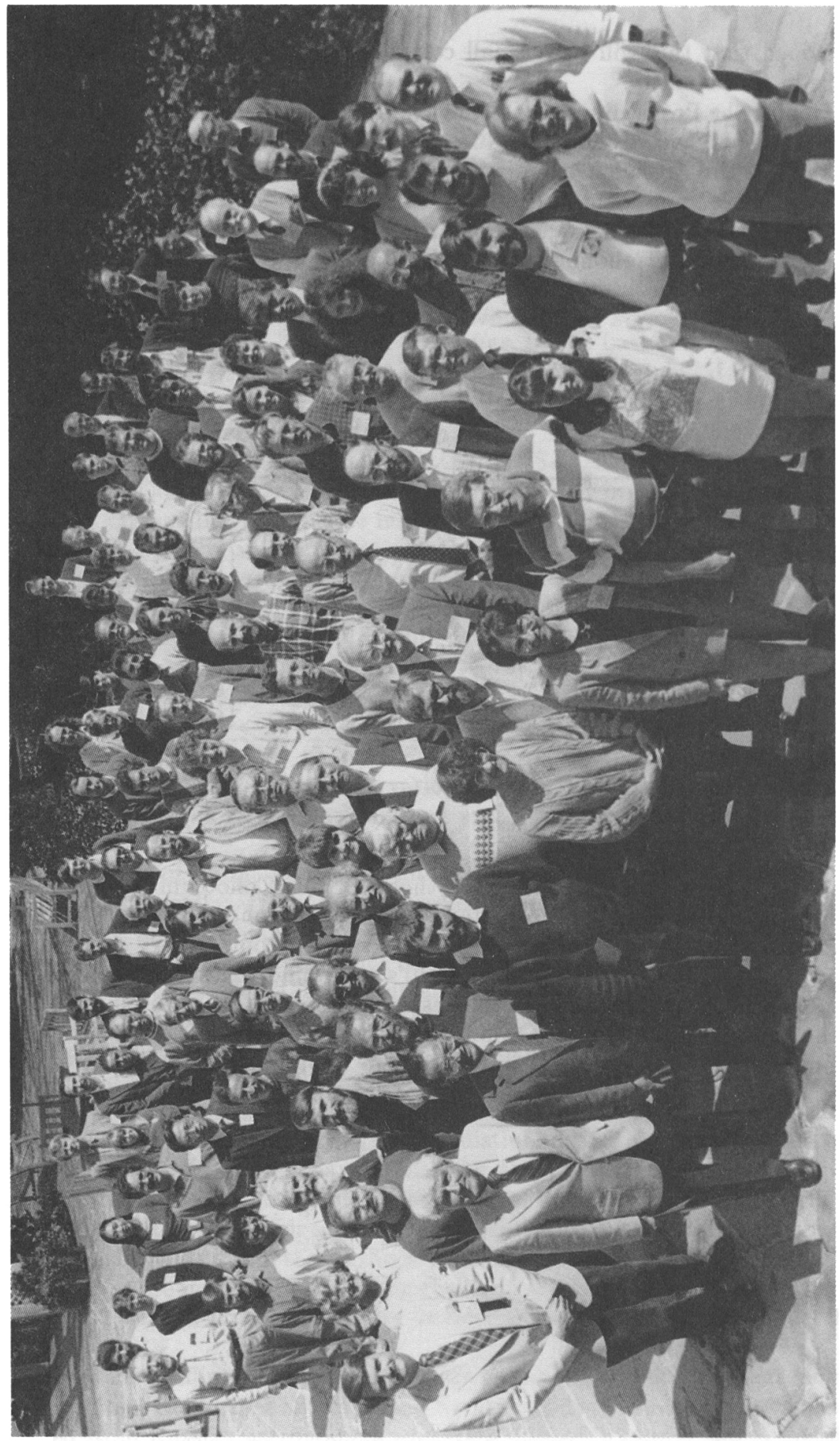




\section{Meeting Photograph}

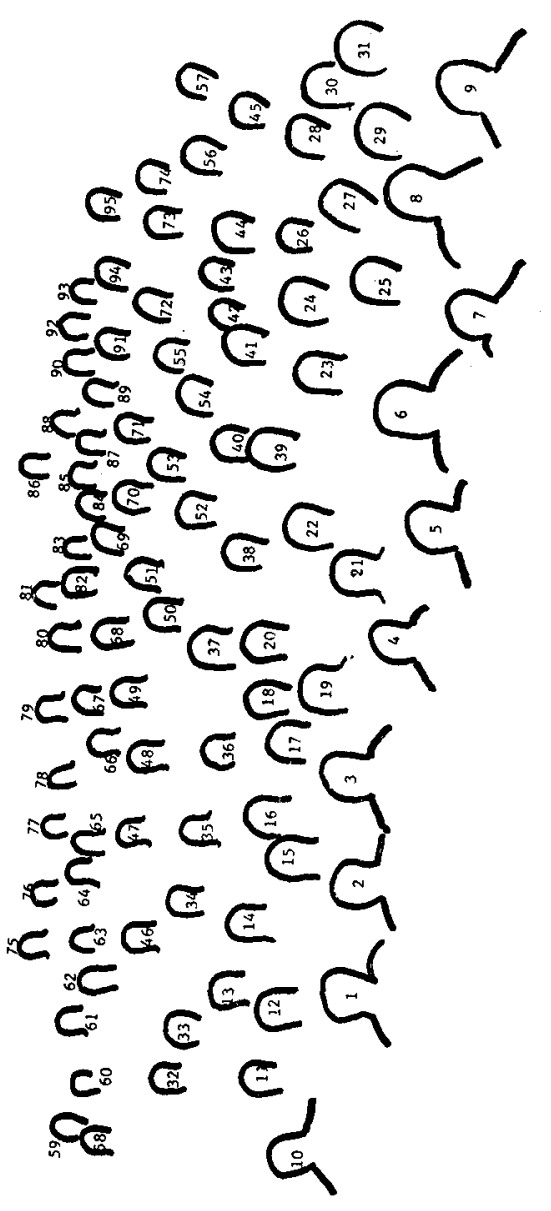

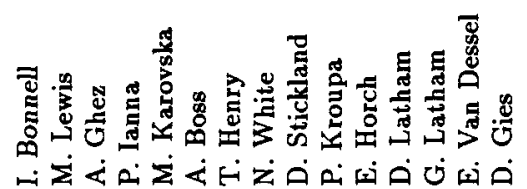
ம்

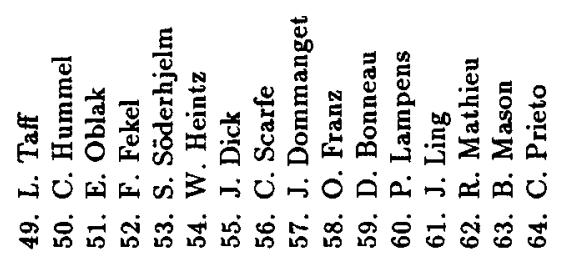

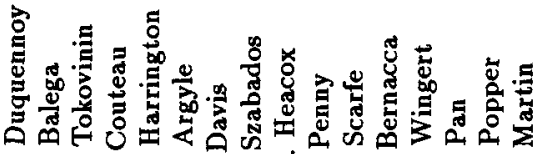

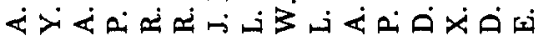

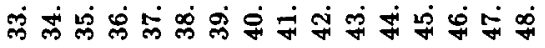

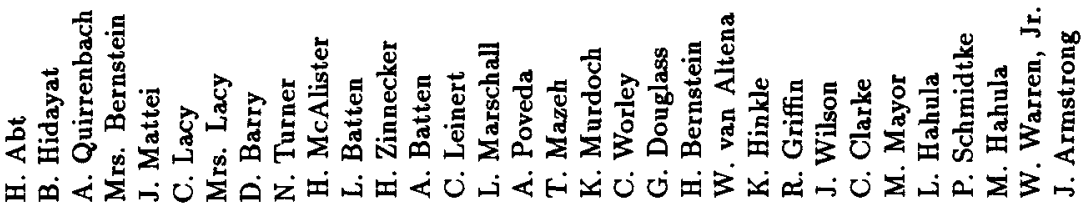

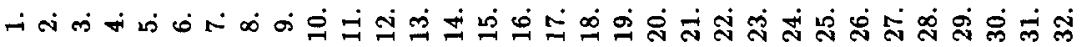

